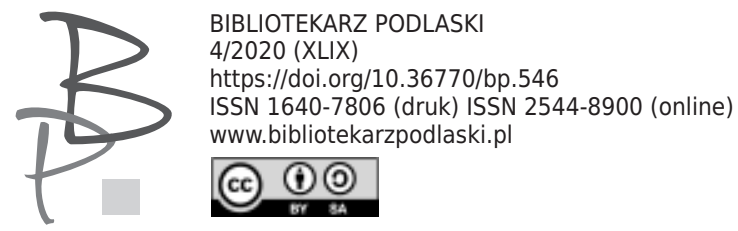

Olesia Naumovska*

Kijowski Uniwersytet Narodowy im. T. Szewczenki, Ukraina

https://orcid.org/0000-0002-9290-7843

\title{
Концепт «смерть» в українській народній казці
}

Concept of «death» in Ukrainian fairy tales

Abstract: The article analyzes the concept of «death» in folklore (fairy tale) text at three levels: 1) as an object (embodied in a concrete character); 2) as a process (implemented through a motive); 3 ) as a spatial concept (expressed through the locus). 1) The anthropomorphic image of death in folk fairy prose functions in many samples of novels. In the Ukrainian folk fairy tale tradition, the character of death is only represented as feminine in gender. Unlike the western European tradition of depicting Death in the form of a skeleton with a scythe, in the Ukrainian tale it is an anthropomorphic character without any signs of decomposition (the scythe as its attribute occurs very rarely in texts). The fairy tale emphasizes features such as death's inevitability, justice, courtesy and nobility. 2) The motive of death as a the protagonist is frequent for magic type fairy tales. The motif of dying mainly concerns the protagonist and is realized through the motives of the hero's journey

* Olesia Naumovska - dr; docent Katedry Folklorystyki Instytutu Filologii Narodowego Uniwersytetu imienia Tarasa Szewczenki w Kijowie (Ukraina). Autorka studium: The multidiversional loci at the otherworld in the folk non-fairy tale prose (2018) 
to the otherworld. It is noteworthy that such a trip is stratified according to the gender principle: the voluntary journey of the hero, connected with the conflict in which the woman is mostly involved, and the forced journey of the heroine, who often does not suspect its true reason - the intention of the antagonist / evil stepmother who wants to see her perish. The motif of the death of the protagonist is predominantly in the enchanting heroic fairy-tales, where it is realized: a) through the swallowing of the hero by a monster, often a fish; b) petrification of the hero as a result of violation of speaking when forced to stay quiet made by demonological beings; c) the murder of a hero by a traitor or antagonist (as a rule, with resurrection of the protagonist with the help of «healing and living water»). 3) The analysis of the texts confirms the presence of both vertical and horizontal planes with semantics of the space of death. The horizontal plane does not have any vector (the fairy tale does not emphasize the eastern, western, southern or northern directions of the hero's movement to the otherworld), but these planes always belong to the boundary space (the most frequent point is the forest). The vertical plane of death's location is underground (lower projection of the vertical vector ") and the celestial (upper projection of the vertical vector ") worlds with the domination over the lower projection (').

Keywords: death, concept, image, motive, locus, folk tale, prose, folklore.

Постановка проблеми. Фольклорна казкова проза, як відомо, є своєрідною квінтесенцією закодованого в художній формі світогляду народутворця. Основою такого світоосягнення стали уявлення про смерть - iї час і причини, простір панування і функції, невідворотність чи, навпаки, можливості уникнення, іiі контрадикція з життям. Поліаспектне вивчення способів реалізації концепту «смерть» в художньому просторі народної казки є одним з інструментів з'ясування панорамної картини світосприйняття наших пращурів й розуміння ними законів життя й смерті.

Аналіз досліджень і публікацій. У вітчизняній гуманітаристиці однією $з$ найгрунтовніших праць, присвячених вивченню концепту «смерть» 


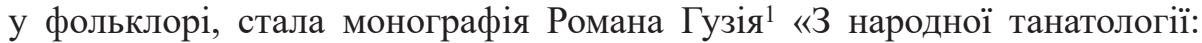
карпатознавчі розсліди». Учений не лише здійснив ретельне дослідження рефлексії явища смерті у різних жанрах усної словесності, а й залучив до нього широкий фактологічний матеріал етнографічного характеру, звичаїв, повір'їв, вірувань тощо, простеживши вияви «життєвої філософії» (персоніфікований образ смерті, вірування про причини смерті, зокрема передчасної, та ін.) й етапність актуалізації «смерті» - від традиційного приготування до помирання до ігор та веселощів у похороннопоминальних обрядах як народних засобів охоронно-продукуючої магії. Розвідка $\epsilon$ цінною для розуміння традиційного народного сприйняття смерті, проте іiі відображення у народній казці показано лише фрагментарно, що залишає простір для подальших студій цієї проблематики у науковому світі.

Глибоко системно аналізуючи українську народну прозу (легенду, казку), не оминає увагою концепту «смерть» і Лідія Дунаєвська. Учена не ставить перед собою завдання всебічного вивчення вияву цього концепту в народній казці, проте окреслює стратегічні вектори аналізу. Так, казкознавиця простежує і просторові, й акціональні, і предметні коди «смерті» у казковій прозі («У казці відображена віра в існування «потойбічного світу», повернення звідти, уявлення про смерть, заховану у певному предметі (яйці, скриньці, голці тощо)»², й смерть як антропоморфний образ («Дидактичні казки < . .>зафіксували уявлення про < . .> щастя, долю, смерть, біду як про антропоморфних істот, від яких залежить життя кожної людини. Казки цієї групи дають своєрідні настанови - як уникнути смерті, біди, злиднів»³), і сюжетну реалізацію концепту «безсмертя» на рівні художніх засобів («Віра в безсмертя людини, в постійне перевтілення іiі у вічноживому світі природи трансформувалася в художній поетичний прийом - метаморфозу» $)$.

1 Р. Гузій, 3 народної танатології: карпатознавчі розсліди, Львів 2007, Інститут народознавства НАН України.

2 Л. Дунаєвська, Украӥнська народна проза (легенда, казка). Еволюиія епічних традииій, Київ 2009, Київський університет, С. 66.

3 Там же, С. 96.

4 Там же, С. 139. 
Із позицій психоаналітики досліджує смерть у закарпатській казці в контексті ініціації героя Оксана Тиховська5. Не вдаючись до дискусії щодо психоаналітичних особливостей української народної казки, не можемо все ж погодитись із висновками дослідниці, яка розмежовує ініціацію («ритуали переходу») у казкових сюжетах на два типи (перший пов'язаний із весільним обрядом, «з властивою йому складною системою традиційних уявлень, пов'язаних 3 набуттям членами подружжя іншого статусу»; другий - пов'язаний із поховальними обрядами, «уявленнями про потойбічний світ та посмертне існування в ньому людини»). У цих висновках зазначається, що у казці зв'язок ініціації з потойбічними уявленнями (ймовірно, маючи на увазі другий тип свого поділу) є «менш виразним» ${ }^{6}$, адже в самій основі ініціації лежить уявлення про помирання індивіда в одній іпостасі й відродження в іншій, на чому наголошує й дослідник ініціацій Василь Балушок: «Головним в усякій ініціації є ритуальне вмирання ініціантів у старій якості з метою подальшого їх відродження, але вже у новому статусі»7. Своє висловлювання про менш виразний зв'язок казкових ініціацій з потойбічними уявленнями дослідниця, ймовірно, будує на основі подібної тези Олександри Бріциної та Галини Довженок, які, втім, додають ремарку - «на перший погляд», що, звісно, цілковито змінює сенс повідомлення. Казкознавиці наголошують: «Проте, якщо пильніше постежити за оповідями, виявляємо чітке розмежування двох світів - “нашого” і “того”. Саме на “той” світ прямує герой у пошуках молодильної води чи яблук, туди він потрапляє, переслідуючи супротивника чи шукаючи зниклу наречену. Цей казковий світ (тридев'яте царство, ліс, море тощо), де звірі розмовляють, а чудесні предмети виконують бажання їх власника, де людина може легко перетворитися на звіра тощо, $є$ безпосередньою аналогією світу мертвих» ${ }^{8} .3$ огляду

5 О. Тиховська, Переосмислення уявлень про смерть та обряд ініціацї̈ в закарпатських народних казках, «Науковий вісник Ужгородського університету. Серія: Філологія», Випуск 14: 2006, C. 190-193.

6 Там же, C. 190.

7 В. Балушок, Обряди ініціацій українців та давніх слов'ян, Львів - Нью Йорк 1998, М. П. Коць, С. 28.

8 O. Бріцина, Г. Довженок, Украӥнські епічні прозові наративи, URL: http://bervy.org. ua/2013/04/ukrajinski-epichni-prozovi-naratyvy/ (25.03.2019). 
на вищесказане, полемічним видається й виокремлення Оксаною Тиховською казкової інтерпретації «вдалої і невдалої ініціації» та твердження, що смерть є лише результатом «невдалої ініціації»: «Казки акцентують увагу на вдалій і невдалій ініціації. Успішність подолання випробувань обряду посвячення гарантує казковому герою чи героїні стабільне соціальне становище, багатство, одруження; неуспішність натомість тотожна виключенню 3 соціуму, вигнанню і в кінцевому результаті - смерті» 9 . Вочевидь, дослідниця трактує «смерть» персонажа казки лише як означену самим сюжетом - приміром, смерть «бабиної дочки» внаслідок невиконання завдань ініціатора у так званих «жіночих казках», побудованих на контрадикції мачухи й сирітки («Кобиляча голова» ${ }^{10}$ й подібні). Однак не слід забувати, що й саме перебування «дідової дочки» у «чужому просторі» (лісовій хатинці) символізує тимчасову смерть героїні, що $€$ рефлексією пубертатних ритуалів, які мали на меті оформлення настання фізичної зрілості й носили індивідуальний характер (на відміну від ініціацій, які супроводжували соціалізацію молоді й були груповими): «Пізніше, з виділенням та зміцненням парної сім'ї, пубертатні обряди все більше набувають сімейного характеру проведення. Такими вони є i сьогодні в тих суспільствах, де продовжують існувати. Ініціації ж ніколи не належали і не належать до обрядів сімейних, вони завжди носять общинно-корпоративний характер» ${ }^{11}$.

Антитезу «життя / смерть» 3 третім логічним компонентом «безсмертя» як генеральну універсально-культурну матрицю дискурсивної структури казки досліджує Олександр Кирилюк, проектуючи казкові сюжети на інстинктивні регулятори поведінки людини: агресивність, мортальність, вітальність, аліментарність, еротичний код, генетив та іммортальність. Учений застерігає від зведення «все і вся» у казці лише до ініціації: «3 одного боку, < ..> будь-який обряд, не дивлячись на його «титул», залучає

9 О. Тиховська, Переосмислення уявлень про смерть та обряд ініціаиії в закарпатських народних казках, «Науковий вісник Ужгородського університету. Серія: Філологія», Випуск 14: 2006, С. 193.

10 Л. Дунаєвська, Золота книга казок : Украӥнські народні казки в записах, переказах та публікаиіях українських письменників, Київ 1990, Радянська школа, С. 298-302.

11 В. Балушок, Обряди ініціiацій українцฺів та давніх слов'ян, Львів - Нью Йорк 1998, М. П. Коць, С. 5-6. 
до себе інші ритуально семіотизовані життєві події, коли, приміром, обряд народження несе в собі матримоніальні мотиви, весілля - поховальні, а погребання - пологові тощо. 3 іншого боку, «ініціальна редукція» $€$ помилковою ще й тому, що відповідні універсально-культурні інтенції свідомості можуть інваріантно структурувати казку безпосередньо в процесі іiі генерації» ${ }^{12}$. Беззаперечно погоджуючись із постулатом Олександра Кирилюка про тріаду «життя-смерть-безсмертя» як універсально-культурну матрицю народної казки і підтримуючи загалом концепцію дослідника щодо впливу регуляторної функції поведінкових інстинктів людини на структуру казкових сюжетів, все ж дозволимо собі поставити під сумнів безапеляційне відкидання ідеї ініціації як сюжетогенератора казкових текстів, оскільки, як уже зазначалося вище, ініціація передбачає перехід 3 одного стану в інший через помирання, що, по суті, і $є$ тріадою «життясмерть-безсмертя», відображеною метафорично у структурі казки.

Саме в контексті ініціації - як ініціальний простір - осмислює «той світ» у казці Віктор Давидюк, акцентуючи на сакральності його атрибутів («чарівний перстень», «шапка-невидимка», «чоботи-скороходи» тощо). Зразком із прямою згадкою про «той світ» учений вважає казку «Ох», однак висловлює гіпотезу щодо маркування казкового тексту номінантами «той світ», «світ за очі», «на край світу», «куди очі світять», «тридев'яте царство» як фольклорну інтерпретацію не міфологічного простору смерті, а «трансформації багатьох історично конкретних уявлень про межі племінних і етнічних угідь та прилеглих дифузних зон і сусідніх недоступних для невтаємничених територій» ${ }^{13}$.

Мета статті - здійснити аналіз різнопланового вияву концепту «смерть» в українській народній казці як ретрансляторові міфопоетичного мислення задля осмислення давніх світоглядних засад українства.

Відтак, об'єктом дослідження $є$ зразки українських народних казок, а предметом - рівні й способи вираження концепту «смерть» у текстовому просторі казкової прози.

12 О. Кирилюк, Універсалії культури і семіотика дискурсу. Казка та обряд, Одеса 2005, Автограф, С. 343.

13 В. Давидюк, Первісна міфологія українського фольклору, Луцьк 2005, Волинська обласна друкарня, С. 73. 
Розуміючи концепт як «елементарну ментально організовану одиницю, яка виконує функцію збереження знань про світ в абстрактному форматі» ${ }^{14}$, або ж, інакше кажучи, як ментефакт етнокультури, що сприяє розумінню цілісної картини світу (оскільки картина світу - це система концептів), розглядатимемо його у фольклорному (казковому) тексті тривимірно: 1) як об'єкт (втілений в конкретний образ); 2) як процес (реалізований через мотив); 3 ) як просторове поняття (виражене через локус).

\section{Концепт «смерть» як об'скт (втілений в конкретний образ казки)}

Антропоморфний образ Смерті в народній казковій прозі функціонує у новелістичних зразках.

Короткий огляд міфології різних народів світу демонструє відсутність універсального гендерного принципу трактування демона смерті, однак із незначним домінуванням маскулінності. Так, в одних міфологічних системах це - істота чоловічої статі (Нергал у шумерській міфології, Танатос у давніх греків, Анубіс у давніх єгиптян, Міктлантекутлі в міфології ацтеків, Ах-Пуч у майя, Яма в індуїзмі і буддизмі, Грох у вірменів та ін.), в інших - жіночої (Хель у давньоскандинавській міфології, Морриган у давніх кельтів, Хіне-нуї-те-по у маорі, банші в ірландському фольклорі, Ідзанамі в японській міфології та ін.). Їх спільними рисами є суворість, невблаганність у поєднанні зі справедливістю і благородством. Ймовірно, поширений з кінця середньовіччя образ персоніфікованої Смерті у чорному балахоні з косою виник у зв'язку з пандемією легеневої чуми в Європі y XIV ст. як вираження масштабу трагедії, сама ж коса як міфема видається модифікацією давнього незмінного атрибуту образів смерті у різних культурах - серпа, який, з одного боку, пов'язаний з уявленнями про взаємозв' язок померлих із плодючістю (відтак, у різних світових міфологічних системах божества потойбіччя водночас впливають на врожайність - приміром, давньоєгипетський володар потойбіччя, небесний суддя, богцар, покровитель і захисник людей Осирис є також богом рослинності, продуктивних сил природи, на знак пошанування якого, як зазначає Тетяна Муравйова, у присвячених йому храмах встановлювали дерев'яну

14 M. Schwarz, Kognitive Semantiktheory und neuropsychologische Realität, Tübingen, Basel 1996, Francke, s. 55. 
раму, подібну контурами до антропоморфного тіла, засипали землею й засівали зерном, яке навесні проростало, символізуючи актуалізацію божественної сили ${ }^{15}$; із цими ж уявленнями пов'язаний і український обряд «Велесова борода» - жертвопринесення у вигляді залишених на полі перших декількох дозрілих нежатих колосків, з яких робили закрутки у жнива, давньослов'янському богу підземного світу, мистецтва й торгівлі, покровителю скотарства, який вважався також помічником та заступником хліборобів), з другого - лунарним символом, що підтверджує уявлення про ніч як про мертву пору доби, з третього - $€$ інструментом стинання голів обраним для помирання (так, давньогрецький бог-медіатор світів, психопомп Харон, який переправляв душі померлих через річку Стікс, міг серпом стинати голови тих, хто не мав обола (монети) для ритуальної плати - навлону, що слугувало утвердженню поховальних традицій: класти під язик померлому монету і обов'язково стежити за збереженням цілісності тіла, оскільки, за міфами, Харон перевозить до потойбіччя для продовження посмертного існування тільки тих померлих, чиї рештки під час поховання складені докупи).

В українській народній казковій традиції образ смерті - виключно жіночого гендеру. При тому, на відміну від типового для західноєвропейської традиції зображення Смерті у вигляді вдягненого у білий чи чорний плащ-балахон із капюшоном скелета 3 косою, відомого як «Похмурий жнець» (Grim Reaper), в українській казці це - цілковито антропоморфний образ, який, окрім того, не має жодних ознак тліну, як правило, вдягнений у звичайний селянський одяг, до того ж коса як його атрибут трапляється у текстах вкрай рідко.

Тому, на нашу думку, саме вплив західноєвропейських уявлень позначився на функції образу Смерті в українській новелістичній казці «Козаки і Смерть» (позбавленого, втім, жодної іншої портретної характеристики) - стинання голови за допомогою коси: «Оце й добре, що я вас, волоцюг, спіткала. Годі вам гуляти та розкошувати, у шовкових жупанах ходити та мед-вино пити, ось я вас із світу зжену, косою голови постинаю!» ${ }^{16}$.

15 Т. Муравьева. Мифы античности и средневековой Европь, Москва 2006, Вече, С. 29.

16 Л. Дунаєвська, Золота книга казок : Украӥнські народні казки в записах, переказах та публікаиіях українських письменників, Київ 1990, Радянська школа, С. 355. 
Прикметно, що погрози Смерті не є її забаганкою, а пов'язані з покаранням за конкретні провини героїв казки в аксіологічній шкалі українця: байдикування, любов до розкоші, пияцтво. Більше того, Смерть постає цілковито лояльною і благородною, виявляє чемність: у відповідь на прохання одного козака востаннє покурити люльку, дає на те дозвіл («Ну, - каже смерть, - коли ти мене милостивою панею назвав, то вже кури собі!»), як і на прохання його товариша: «...дай і мені пільгу! - каже другий козак. - Дозволь мені перед смертю табаки понюхати!» - «Нюхай, - каже, - та знай мою добрість». За мотивом казки «обдурити смерть», чи, іншими словами, наївністю як оприявленою рисою образу, легко «прочитуються» народні уявлення про справедливість і благородство Смерті, яка, вдихнувши дим та понюхавши тютюн, дарує козакам життя: «І як се ти таке паскудство вживаєш?! < ..> Коли так, не буду ж я вас косою стинати! То не штука - вмерти, а от ти чхай ще 50 літ!»

Значно більшою мірою комічно зображується образ Смерті у казці «Солдат і Смерть», що свідчить, на наш погляд, про певне нівелювання традиційного народного світогляду, а отже - пізніший час творення казки. Аналізований персонаж у зазначеному тексті повністю позбавлений портретних характеристик - про жіночий гендер і поважний вік свідчить лише форма звертання до нього. Так, герой твору, солдат, помирає і потрапляє спершу до пекла, де допікає чортам, яким врешті вдається його позбутися, а потім - до раю, де, чекаючи на прийом до Бога, бачить Смерть і промовляє до неї так: «Бабусю, чуєш? Ти це куди?» ${ }^{17}$. Про пізній час творення зразка свідчить і наявність самих локусів раю і пекла, і гумористичний тон їх опису, і метафора на позначення основної функції Смерті - «пожирання» людей, i, безумовно, мотив обману Смерті, за яким солдатові вдається неодноразово іiі перехитрувати, що суперечить традиційним народним віруванням та уявленням. Розв'язка твору - знищення Смерті за допомогою чарівної торбинки всупереч волі самого Бога, який наказує Смерті умертвити солдата («А солдат розшморгнув торбинку та: «А в торбинку!» Вона у неї

17 Л. Дунаєвська, 3 живого джерела : Українські народні казки, Київ 1990, Веселка, C. 164. 
і вскочила. Він зашморгнув ії̈ там та й закинув у болото»), сприймається як гротескна форма презентації одвічної проблеми людства - пошуку рецептів безсмертя.

Попри те, художня форма казки зберігає й рефлексії давнього світогляду, оскільки побудована на багаторазовому різноплановому конструкті - сакральному числі «життя» - «три»: «прослужив солдат у царя тридцять три роки»; «дав йому цар три копійки»; чотири рази «перестрівають його три старці», тричі 3 них він дає трьом старцям по три копійки; «три просьби» солдата виконують три старці, внаслідок чого солдат отримує три чарівні предмети-властивості: постійні «гроші в кармані», люльку, щоб «не накладать і не закурювать, а як загадаю, щоб сама готова була», торбинку таку, «що я про що не подумаю, зараз щоб там і було»; три питання солдат ставить чортам: «горілка $€ ? »$, «тютюн $\epsilon$ ?», «огонь $\epsilon$ ?», почувши ствердні відповіді на які, доходить висновку: «От рай, так рай!»; тричі солдат обманює Смерть, перекручуючи накази Бога їсти спершу старих, потім молодих людей і врешті дітей, і передає їй тричі по три роки гризти «старі дубки», «самі середні дубки», «самі молоді дубки». Прикметно, що казка відображає риси християнського світогляду, оскільки в цьому сюжеті Смерть беззаперечно виконує волю Бога.

На противагу цьому, у казці «Кума Смерть» Смерть постає невідворотною, непідвладною жодним хитрощам і обману. Так, Смерть береться допомогти своєму кумові стати великим лікарем і розбагатіти: «Як я буду сидіти в ногах слабого, то це значить, що він буде жити. Беріться його лікувати. А як побачите, що я сиджу в головах, то знайте, що він не буде жити, і зразу кажіть людям, най готують дошки на труну. А як я буду сидіти коло якого слабого, то лиш ви мене будете бачити, більш ніхто» ${ }^{18}$. Коли ж наближається час помирати героєві, кума вказує йому на свічки, рівень згорання яких показує, скільки людині ще відведено життя, і радить лаштувати труну. Намагаючись перехитрити Смерть, кум просить коваля зробити в його колисці потаємну пружину, за допомогою якої двічі йому вдалося перекрутитися, однак втретє - ні: «знов ногою

18 Л. Дунаєвська, Золота книга казок : Українські народні казки в записах, переказах та публікачіях украӥнських письменників, Київ 1990, Радянська школа, С. 356. 
торкнув, але баба вхопилася за колиску і перебирає руками, підступає до голови. Він хотів ще раз повернути колиску, але вже не зміг. А Смерть каже: «Куме, крути - не крути, мусиш умерти». Зовнішність персонажа Смерті у казці наділена рисами типової селянської жінки («Вертається він додому і здибає якусь чужу бабу»), тож герой спершу навіть не здогадується, що його кума - сама Смерть: «Куме, ви знаєте, що я за одна?» - «Ви - кума». - «Кума-то кума, але я - Смерть». У цьому зразку, як і в казці «Козаки і Смерть», акцентовано на благородстві Смерті, яка єдина погоджується стати кумою для бідної родини й упродовж багатьох років допомагає героєві.

Такою ж справедливою й шляхетною є Смерть у казці «Життя i Смерть», яка, як і в попередньому тексті, зображується звичайною селянкою, яку вирізняють лише кістляві руки: ««Хто ти?» - питає чоловік. «Не впізнаєш? Я - Смерть»»; «Простягнула Смерть кістляві руки» ${ }^{19}$. Шляхетність Смерті підкреслюється мотивом ії згоди замість хворого хлопчика забрати «на той світ» будь-кого, хто погодиться добровільно, однак ні батько, ані сестра не зважуються на таких крок, на відміну від матері, яка, попросивши дозволу попрощатися 3 сином, «...вийшла надвір, дивиться: де Смерть? А довкола нікого не видно. Тільки на дорозі хтось дибає геть. «Чекай!» - гукнула мати. Та ії не чули. Мати знову забігла до хати. Бачить - син усміхнений, здоровий».

Загалом же, персоніфікований образ Смерті властивий соціальнопобутовій, переважно новелістичній, українській народній казці.

\section{Концепт «смерть» як процес (реалізований через мотив)}

Частими для чарівної казки є мотиви помирання та загибелі добротворця.

Мотив помирання в основному стосується протагоністів і реалізується шляхом мотивів подорожі героя до потойбіччя. Прикметно, що така подорож стратифікується залежно від гендерного принципу: добровільна подорож героя і примусова - героїні.

Більше того, мотив помирання через добровільну подорож героя до потойбіччя так чи інакше пов'язана з конфліктом, у якому здебільшого

19 Там же, С. 358. 
задіяна жінка: визволяти сестру і братів йде до змієвих володінь Покотигорошко: «Іду до змія - сестри одіймать» ${ }^{20}$ («Покотигорошко»); веде весільний поїзд свого брата сватати зміївну Іван Голик: «Піди ж ти своєму князеві скажи, що їде він свататися, та без мене не посватається» ${ }^{21}$ («Казка про Івана Голика і його брата»); немов знаючи наперед, що знайде своє кохання, вирушає на «той світ» Іван-Вітер: «А сам пішов у світ і зайшов у пущу. Надибав палац. Зайшов у той палац, а в тім палаці змій безсмертний Козьолок жив. I в тім палаці була дуже ладна пані» 22 («Іван-Вітер»); обіцяний батьком змії, герой казки «Яйце-райце» йде до іï володінь, де й зустрічає свою майбутню дружину23; до тридесятого царства віднімати у Баби Яги - костягої ноги свою дружину йде Іван-царенко: «Іду, - каже, - дідусю, світ за очі, шукати своєї жінки; вона десь у тридесятім царстві, у Баби Яги - костяної ноги, іду, та й не знаю куди...» ${ }^{24}$ («Царівна-жаба»); зустріч героя 3 майбутньою дружиною як винагорода за «чарівну науку» у підземному світі $є$ сюжетною розв' язкою казок «Ох » ${ }^{25} \mathrm{i}$ «Гайгай» ${ }^{26}$ та інших.

На противагу цьому, як уже зазначалося вище, найчастіше мотив помирання героїні розгортає мотив іï примусової подорожі до потойбіччя (за незначними винятками, на кшталт сюжетного типу казки «Красносвіт», в якому події розвиваються аналогічно до казок із порушенням табу таких, як «Царівна жаба», однак функції героя дзеркально перенесено на героїню) у «жіночій» казці, при тому часто героїня не здогадується про iï справжню причину - прагнення злотворця / мачухи звести іiї зі світу. Такими прикладами $є$ казки, події в яких розгортаються довкола конфлікту мачухи і сирітки: «Про кобилячу голову» ${ }^{27}$, «Дідова дочка й бабина

20 Л. Дунаєвська, Золота книга казок : Українські народні казки в записах, переказах та публікачіях українських письменників, Київ 1990, Радянська школа, С. 97.

21 Там же, С. 102.

22 Там же, С. 112.

23 Там же, С. 203-210.

24 Там же, С. 201.

25 Там же, С. 214-220.

26 Там же, С. 210-214.

27 Там же, С. 298-302. 
дочка» ${ }^{28}$, «Про дідову дочку та бабину дочку» ${ }^{29}$ та подібні. Привертає увагу пасивна роль рідного батька сирітки, який за наказом мачухи власноруч відводить до лісу на погибель рідну доньку, у чому вбачається домінантна функція жінки та виявляються ознаки важливої ролі материзни як спадкового жіночого права, властивого традиційному українському суспільству.

Мотив загибелі добротворця наявний переважно у чарівних богатирських казках, де реалізується: а) через проковтування героя чудовиськом часто рибою: «Тільки що батько сина у море пхнув, його кит-риба зараз і вхопила» ${ }^{30}$ («Казка про Івана Голика і його брата»); б) скам'яніння героя внаслідок порушення ним заборони демонологічних істот на мовчання: «От він і розказав про те, що чув од тих трьох зозуль, і як розказав, то по шию каменем став» («Про Богатиря Сухоброзденка Йвана і Настасію Прекрасную» ${ }^{31}$ ); в) убивство героя зрадником чи антагоністом (з майбутнім, як правило, воскресінням добротворця за допомогою «цілющої і живлющої води»): «Як кинув ним, то так кісточки порозліталися. Козьолок узяв кістки та заховав під деревом»; «Взяла мама покропила його цілющою водою, він і ожив. Покропила живлющою - він зцілився» 32 («Іван-Вітер»). Прикметно, що у разі перемоги добротворця над злотворцем герой пильнує, аби зруйнувати тіло супротивника, 3 чого можна зробити висновок про віру в продовження життя після смерті у потойбіччі чи воскресіння за умови збереження цілісності тіла, що властиво було і східним культурам, зокрема Давнього Єгипту, на чому акцентує Тетяна Муравйова, пояснюючи виникнення інституту бальзамування: «Вкрай важливою умовою для успішного життя за гробом було збереження тіла померлого»33. Так, у згаданій казці Іван-Вітер «взяв те

28 Л. Дунаєвська, Золота книга казок : Украӥнські народні казки в записах, переказах та публікаиіях українських письменників, Київ 1990, Радянська школа, С. 364-369.

29 Л. Дунаєвська, 3 живого джерела : Українські народні казки, Київ 1990, Веселка, C. 210-214.

30 Л. Дунаєвська, Золота книга казок: Украӥнські народні казки в записах, переказах та публікаиіях украӥнських письменників, Київ 1990, Радянська школа, С. 101.

31 Там же, С. 149.

32 Там же, С. 112.

33 Т. Муравьева. Мифы античности и средневековой Европы, Москва 2006, Вече, С. 29. 
яйце, розбив собі на голові, і вся сила пішла по нім. А той Козьолок відразу вмер. Тоді Іван-Вітер взяв його порубав і викинув собакам» ${ }^{34}$; у казці «Про Сученка-богатиря» царівна «...звеліла яму викопати і половину жару напалити і перемостила дрючок через яму», «торкнула ногою дрючок повернувся, а цар у вогонь упав» ${ }^{35}$; Чабанець із однойменної казки «як шмагоне його [змія - O. H.] тим камінцем, - змій тут і розпластавсь, і дим пішов у трубу» 36 тощо.

\section{Концепт «смерть» як просторове поняття (виражене через локус)}

Аналізуючи концепт «смерть» у художньому просторі народної казки, не можна оминути увагою і локуси потойбіччя як простір панування смерті. Учені неодноразово наголошували на прадавніх міфологічних уявленнях про вертикальну (хтонічну, земну і небесну) та горизонтальну просторових межах світобудови, трансльованих фольклорними текстами, зокрема чарівною казкою. Як зазначає Лідія Дунаєвська, «кожна чарівна казка $є$ художньою проекцією на три (дві) вертикальні площини - головні персонажі ініціюються поза межами реального оточення» ${ }^{37}$. Аналіз текстів засвідчує наявність і вертикальних, і горизонтальних площин із семантикою простору смерті. Горизонтальна площина не має жодної векторності (казка не акцентує на східному, західному, південному чи північному напрямку руху героя на «той світ»), однак ці площини завжди належать до межового простору. Найчастотнішим локусом горизонтальної площини є ліс. Наприклад, на полюванні в лісі, стомившись і промокнувши від дощу, пан промовляє: «От якби нам тепер хата тепла, постіль біла, хліб м'який, квас кислий - нічого б і журиться: казали б казку, баяли б байку до самого світа», - й перед ним та товаришами з'являється чарівна хатинка й усе, що він забажав, але через порушення ним обіцянки оповідати казки до ранку тричі - опівночі, «об других» i «об третіх» півнях

34 Л. Дунаєвська, Золота книга казок : Украӥнські народні казки в записах, переказах та публікаціях украӥнських письменників, Київ 1990, Радянська школа, С. 113.

35 Там же, С. 137.

36 Там же, С. 100.

37 Л. Дунаєвська, Украӥнська народна проза (легенда, казка). Еволюиія епічних традииій, Київ 2009, Київський університет, С. 61. 
під вікном нечиста сила виголошує обставини його загибелі («Лови» ${ }^{38}$ ). Саме у лісі, куди іiї випроваджує мачуха, сирітка проходить ініціації та гине «бабина дочка» у згаданих вище «жіночих» казках. Таких прикладів є досить багато в українській казковій традиції.

Вертикальна площина локусу смерті розміщена у підземному (нижня проекція вертикального вектору ') та небесному (верхня проекція вертикального вектору •) світах. В українській казковій традиції превалює нижня проекція ('): під землею, у володіннях потойбічного господаря проходять сакральну «науку» герої казок «Ох» $\mathrm{i}$ «Гайгай»; до своєї «нори» затягує змій сестру Покотигорошка в однойменній казці, куди потім герой іде визволяти iї та братів; у норі ж під землею - світ, у якому живе чарівна «баба», яку не може подолати богатир Сухоброзденко Василь, а наздоганяє і вбиває його брат Сухоброзденко Іван («Про богатиря Сухоброзденка Йвана і Настасію Прекрасну» ${ }^{39}$ ) тощо. Значно рідше (в основному в західноукраїнських казках) трапляються зразки, в яких локус потойбіччя розташований у верхній проекції вертикального вектору (•). Такими, приміром, $є$ казки «Шовкова держава», де на горі розташований інший світ, сповнений демонічних істот: «стара бабище» «тче не полотно, а військо» та височіє палац Песиголовця ${ }^{40} ;$ «Про золоту гору», в якій троє братів («старшому було одинадцять років, середущому - десять, а самому найменшому - допіро ще сім років») дізнаються, що «в такім-то царстві, в такім-то государстві, там-то і там-то єсть золоті гори і хто ті гори одбере од зміїв, то тому цар пів свого царства оддасть», і вирушають на боротьбу зі зміями, яких, врешті, перемагає брат-семиліток ${ }^{41}$. Наголосимо, що боротьба героя-добротворця зі змієм і остаточна перемога протагоніста у казковому тексті символізують космогонічний акт: утвердження космосу шляхом подолання хаосу.

Висновки. Проведений аналіз засвідчив прояв концепту «смерть» у художньому просторі української народної казки на трьох рівнях: образ, мотив, локус.

38 Л. Дунаєвська, Золота книга казок : Украӥнські народні казки в записах, переказах та публікаиіях українських письменників, Київ 1990, Радянська школа, С. 86.

39 Там же, С. 137-149.

40 Там же, С. 119-127.

41 Там же, С. 167-170. 
1. Антропоморфний образ Смерті - жіночого гендеру, без жодних ознак тління, коса як його атрибут трапляється у текстах дуже рідко, з акцентацією на таких рисах, як невідворотність, справедливість, чемність і шляхетність.

2. Частими для чарівної казки є мотив помирання, що реалізується через мотиви подорожі героя до потойбіччя, та загибелі добротворця. Подорож героя стратифікується залежно від гендерного принципу: добровільна подорож героя, пов'язана з конфліктом, у якому здебільшого задіяна жінка, і примусова подорож героїні. Мотивема загибелі добротворця наявна переважно у чарівних богатирських казках, де вона реалізується:

а) через проковтування героя чудовиськом - часто рибою;

б) скам'яніння героя внаслідок порушення ним заборон демонологічних істот на мовчання;

в) убивство героя зрадником чи антагоністом (з майбутнім, як правило, воскресінням добротворця за допомогою «цілющої і живлющої води»).

3. Аналіз текстів засвідчує наявність і вертикальних, і горизонтальних площин із семантикою простору смерті. Горизонтальна площина локусу смерті не має жодної векторності, однак завжди належить до межового простору (найчастотнішим локусом $\epsilon$ ліс). Вертикальна площина розміщена у підземному (нижня проекція вертикального вектору ') та небесному (верхня проекція вертикального вектору •) світах із домінуванням нижньої проекції (').

\section{Література}

В. Балушок, Обряди ініціацій українців та давніх слов'ян, Львів - Нью Йорк 1998, М. П. Коць.

О Бріцина, Г. Довженок, Українські епічні прозові наративи, URL: http://bervy. org.ua/2013/04/ukrajinski-epichni-prozovi-naratyvy/ (25.03.2019).

Р. Гузій, 3 народної танатології: карпатознавчі розсліди, - Львів 2007, Інститут народознавства НАН України.

В. Давидюк, Первісна міфологія українського фольклору, Луцьк 2005, Волинська обласна друкарня. 
Л. Дунаєвська, Українська народна проза (легенда, казка). Еволюція епічних традицій, Київ 2009, Київський університет.

Л. Дунаєвська, 3 живого джерела : Українські народні казки, Київ 1990, Веселка.

Л. Дунаєвська, Золота книга казок : Українські народні казки в записах, переказах та публікаціях українських письменників, Київ 1990, Радянська школа.

О Кирилюк, Універсалії культури і семіотика дискурсу. Казка та обряд, Одеса 2005, Автограф.

Т. Мурвьева. Мифы античности и средневековой Европы, Москва 2006, Вече.

О Тиховська, Переосмислення уявлень про смерть та обряд ініціації в закарпатських народних казках, «Науковий вісник Ужгородського університету. Серія: Філологія», Випуск 14: 2006, С. 190-193.

M. Schwarz, Kognitive Semantiktheory und neuropsychologische Realität, Tübingen, Basel 1996, Francke.

\section{Bibliografia}

Balushok V., Obryady' iniciacij ukrayinciv ta davnix slov'yan, L’viv - N`yu Jork 1998, M. P. Kocz' .

Bricy 'na O., G. Dovzhenok, Ukrayins 'ki epichni prozovi naraty 'vy', URL: http:// bervy.org.ua/2013/04/ukrajinski-epichni-prozovi-naratyvy (25.03.2019).

Davy dyuk V., Pervisna mifologiya ukrayins `kogo fol’kloru, Lucz`k 2005, Voly`ns`ka oblasna drukarnya.

Dunayevs`ka L., Ukrayins `ka narodna proza (legenda, kazka). Evolyuciya epichny'x trady 'cij, Ky`yiv 2009, Ky`yivs`ky`j universy tet.

Dunayevs`ka L., Z zhy 'vogo dzherela : Ukrayins 'ki narodni kazky', Ky`yiv 1990, Veselka.

Dunayevs`ka L., Zolota kny`ga kazok : Ukrayins`ki narodni kazky`v zapy`sax, perekazax ta publikaciyax ukrayins 'ky'x py's 'menny 'kiv, Ky`yiv 1990, Radyans`ka shkola.

Guzij R., Z narodnoyi tanatologiyi: karpatoznavchi rozslidy`, L`viv 2007, Insty` tut narodoznavstva NAN Ukrayiny`.

Ky`ry 'lyuk O., Universaliyi kul 'tury ' i semioty `ka dy `skursu. Kazka ta obryad, Odesa 2005, Avtograf. 
Murv'eva T., My 'fy anty 'chnosty ' y' srednevekovoj Evropy, Moskva 2006, Veche. Schwarz M., Kognitive Semantiktheory und neuropsychologische Realität, Tübingen, Basel 1996, Francke.

Ty xovs `ka O., Pereosmy `slennya uyavlen ` pro smert` ta obryad iniciaciyi v zakarpats 'ky ‘x narodny ‘ $x$ kazkax, «Naukovy `j visny`k Uzhgorods' kogo universy` tetu. Seriya: Filologiya» 2006, Vy` pusk 14, S. 190-193. 